\title{
PROGRAM INSPIRASI BELAJAR BAHASA ASING BAGI REMAJA DALAM MENGHADAPI ERA GLOBALISASI
}

\author{
Arianty Visiaty ${ }^{1 *}$, Lusi Lian Piantari ${ }^{2}$ \\ ${ }^{1}$ Bahasa dan Kebudayaan Jepang, Fakultas Ilmu Pengetahuan Budaya, Universitas Al Azhar Indonesia, \\ Jl. Sisingamangaraja, Kompleks Masjid Agung Al Azhar, Jakarta 12110 \\ ${ }^{2}$ Bahasa dan Kebudayaan Inggris, Fakultas Ilmu Pengetahuan Budaya, Universitas AL Azhar Indonesia, \\ Jl. Sisingamangaraja, Kompleks Masjid Agung Al Azhar, Jakarta 12110 \\ Email Penulis Korespondensi: ariantyvisiaty@uai.ac.id
}

\begin{abstract}
Abstrak
Masalah yang dihadapi oleh Panti Asuhan Harapan Remaja adalah kurangnya motivasi dan inspirasi anak asuh siswa SMP untuk belajar bahasa asing. Tujuan dari kegiatan ini adalah menumbuhkan motivasi dan inspirasi belajar bahasa asing untuk belajar bahasa asing. Salah satu cara untuk menunbuhkan motivasi dan isnpirasi belajar bahasa asing adalah dengan dilakukannya pengenalan bahasa asing dengan konteks yang dekat dengan keseharian anak asuh/siswa. Untuk itu telah diadakan program penumbuhan motivasi dan inspirasi berbahasa asing terutama bahasa Jepang dan Inggris masing-masing selama 2 kali. Hasil dari kegiatan ini adalah munculnya ketertarikan siswa terhadap bahasa asing dan ketertarikan untuk belajar bahasa asing terutama bahasa Inggris dan Jepang. Selain itu terlihat juga peningkatan motivasi belajar bahasa asing selain pelajaran sekolah. Akan tetapi tidak ada peningkatan ketertarikan untuk berinteraksi dengan orang asing. Saran kegiatan ke depan adalah mengadakan yang berkelanjutan dan berkala.
\end{abstract}

Kata kunci: Bahasa Asing, Inspirasi, Motivasi

\begin{abstract}
This community service activity had purposes to inspire and motivate the junior high school students to learn a foreign language at the Harapan Remaja Orphanage. This orphanage has a problem dealing with foster children's motivation in learning foreign languages. The result of this activity is the emergence of an interest in foreign languages and learning those languages, especially English and Japanese. After the activities, the result shows that the learners' motivation is still low. However, the activities related to foreign languages increased the participants' interests to learn foreign languages, in this context, Japanese and English. It is suggested that the activity can be carried out continuously because raising inspiration and motivation requires enough time.
\end{abstract}

Keywords: Foreign language, Inspiration, Motivation,

\section{PENDAHUluaN}

Pada era globalisasi saat ini kemampuan bahasa asing sangat diperlukan. Ditambah lagi dengan ditandatanganinya deklarasi blueprint Masyarakat Ekonomi ASEAN (MEA) oleh sepuluh kepala negara di Singapura pada November 2007, yang menyepakati dijalankannya pasar bebas termasuk pasar tenaga kerja pada tahun 2015, maka persaingan tenaga kerja di dalam maupun luar negeri terutama (ASEAN) menjadi sangat ketat. Salah satu kemampuan yang dibutuhkan dalam menghadapi persaingan tersebut adalah kemampuan bahasa asing.

Tidak hanya itu saja kemampuan bahasa asing sangat diperlukan untuk mengembangankan pengetahuan. Kita dapat 
belajar banyak dari negara-negara lain yang lebih maju dalam berbagai bidang keilmuan apabila menguasai bahasa asing. Di antaranya bidang teknologi, budaya, dll. Hal yang sangat penting dalam belajar di suatu bidang tertentu adalah ketertarikan terhadap bidang tersebut, termasuk bahasa asing. Di Indonesia sendiri, termasuk di Jakarta yang merupakan ibu kota negara Indonesia, yang sangat mudah bersentuhan dengan akses bahasa asing pun masih banyak kaum remaja yang tidak tertarik dengan bahasa asing. Hal ini dapat dikarenakan karena ketidaktahuan akan manfaat belajar bahasa asing, prasarana yang tidak memadai akibat masalah ekonomi, dll.

Masalah ini juga dihadapi oleh remaja Panti Asuhan Harapan Remaja yang terdapat di Tenggiri no. 37 Rawamangun Jakarta Timur. Panti asuhan harapan remaja didirikan pada: 4 Desember 1976. Panti asuhan ini mengasuh anak/remaja usia SD sampai SMA, tidak hanya anak/remaja yang tinggal di panti, tetapi juga anak/remaja yang tinggal di sekitar panti. Jumlah anak asuh panti asuhan remaja adalah 117 orang yang terdiri dari 67 anak/remaja yang tinggal di panti (SD: 9 orang, SMP: 25 orang, SMA: 33 Orang), dan 50 anak/remaja di sekitar panti (SD: 25 orang, SMP: 16 Orang, SMA: 12 Orang).

Kurangnya ketertarikan remaja khususnya remaja SMA panti asuhan ini terlihat dari nilai rapot bahasa Inggris yang sangat kurang dan seringnya remaja tersebut absen pada mata pelajaran bahasa Inggris di sekolah. Beberapa anak juga sudah mengikuti kursus bahasa Inggris yang disediakan oleh panti asuhan, tetapi secara umum mereka belum memahami pentingnya kemampuan berbahasa untuk masa depan mereka dan belum bisa menikmati pelajaran bahasa asing tersebut.

Faktor penyebab kurangnya ketertarikan ini di antaranya adalah kurangnya motivasi belajar bahasa Asing. Padahal sebagaimana yang dikemukakan oleh Alizadeh (2016) motivasi merupakan faktor yang sangat penting dalam menentukan keberhasilan pembelajaran bahasa. Hal ini dikarenakan remaja tersebut tidak merasakan/mengetahui manfaat dari bahasa asing tersebut. Yang kedua adalah kurangnya paparan yang dapat menginspirasi bahasa asing. Berbeda dengan anak/remaja dikalangan menengah dan menengah ke atas, anak remaja dipanti sangat minim bersentuhan dengan bahasa asing. Ke tiga adalah kurangnya akses/sarana untuk belajar bahasa asing. Di panti asuhan harapan remaja, hanya terdapat satu TV dan radio yang dipakai bersama. Telepon genggam bersama yang hanya bisa dipakai pada jam-jam tertentu, dan komputer yang hanya dipakai sesuai instruksi pengurus panti, oleh karena itu prasarana untuk belajar bahasa asing sangat terbatas. Kurangnya paparan bahasa asing dan prasarana ini dikarenakan kondisi ekonomi. Untuk menumbuhkan insprasi belajar bahasa asing, pada remaja/anak dalam situasi tersebut di atas maka perlu program khusus yang disesuaikan dengan kondisi mereka. Untuk itu program ini diselenggarakan dengan memperhatikan kondisi dari remaja/siswa tersebut.

Solusi yang telah dilakukan oleh panti asuhan harapan selama ini adalah dengan memanggil guru les bahasa Inggris ke panti asuhan, akan tetapi hal itu tidak membuat anak asuh semangat belajar bahasa asing. Hal ini dapat dikarenakan karena materi yang diajarkan jauh dalam konteks keseharian anak asuh/siswa.

Program Inspirasi ini diharapkan mampu menginspirasi para remaja SMA di panti asuhan 'Harapan Remaja' untuk mempelajari bahasa asing khususnya bahasa Inggris dan bahasa Jepang. Program ini mengadaptasi apa yang dikemukakan oleh Dornyei (2001) bahwa motivasi perlu diperhatikan di kelas untuk meningkatkan proses pembelajaran. Lebih jauh lagi, melalui program ini para remaja tersebut diharapkan mampu untuk mengenali berbagai bentuk akses yang memungkinkan mereka untuk belajar bahasa Inggris dan bahasa Jepang dengan cara dan dari sumber yang beragam. Program ini juga memberikan beberapa teknik dan metode belajar bahasa asing yang menarik dan interaktif. Diharapkan dengan teknik dan metode ini, para remaja khususnya yang berada di panti asuhan tersebut. Teknik pengajaran bahasa asing yang interaktif menstimulus para peserta untuk belajar bahasa asing. Bahasa asing merupakan suatu keterampilan yang memerlukan metode dan teknik khusus dalam pengajarannya. Oleh karena itu Program Inspirasi ini akan membuka wawasan para peserta mengenai pengajaran dan pembelajaran bahasa asing.

\section{METODE PELAKSANAAN}

Metode untuk menumbuhkan inspirasi belajar bahasa asing pada anak/remaja disfungsi sosial dan ekonomi rendah ini adalah dengan 
diselenggarakan Kelas Penumbuhan Inspirasi untuk belajar bahasa asing dengan memperhatikan kondisi serta prasarana yang ada di sekitar remaja tersebut.

Pelaksanaan Program Inspirasi ini dilakukan melalui beberapa tahap. Tahap pertama adalah menyebarkan angket mengenai inspirasi dan motivasi untuk belajar bahasa asing terutama bahasa Inggris dan bahasa Jepang. Angket ini berisikan informasi pribadi dari responden, masa belajar bahasa asing, sejauh mana mereka telah mempelajari kedua bahasa asing tersebut (Bahasa Inggris dan Bahasa Jepang), dan tingkat ketertarikan atau minat mereka mempelajari kedua bahasa asing tersebut.

Tahap kedua adalah tahap pengenalan terhadap bahasa Inggris dan bahasa Jepang. Pada tahap ini dilakukan pengajaran bahasa Inggris dan Jepang dengan metode dan teknik yang interaktif dan menarik, seperti pengenalan kosakata, struktur kalimat, ekspresi-ekspresi yang digunakan dalam kehidupan sehari-hari. Kelas pengenalan ini akan dilakukan sebanyak dua pertemuan untuk masing-masing bahasa.

Tahap ketiga yang merupakan tahap terakhir penyebaran angket yang kedua, untuk mengetahui perubahan tingkat ketertarikan responden untuk belajar bahasa asing. Seluruh hasil kegiatan tersebut kemudian akan dipaparkan kepada mitra dalam bentuk laporan secara lisan dan tertulis. Diharapkan apa yang disampaikan dalam laporan tersebut akan dapat ditindaklanjuti untuk meningkatkan motivasi para responden dalam belajar bahasa asing. Target luaran pada kegiatan pengabdian kepada masyarakat ini adalah:

1. Tumbuhnya inspirasi belajar bahasa asing

2. Laporan pertumbuhan inspirasi belajar bahasa asing pada remaja

\section{Waktu dan Tempat Pelaksanaan}

Pelaksanaan kegiatan kelas inspirasi belajar bahasa Jepang dilakukan di Panti Asuhan Harapan Remaja, Rawamangunm Jakarta Timur, sebanyak empat kali yang terdiri dari dua tahap kelas bahasa Inggris, dan dua tahap kelas bahasa Jepang. Keterangan lebih detail dapat dilihat pada tabel berikut ini.

Tabel 1. Jadwal Pelaksanaan Program Inspirasi Belajar Bahasa Asing

\begin{tabular}{lll}
\hline Bahasa & Waktu Pelaksanaan & Jumlah \\
\hline Bahasa & Jumat/24 Agustus 2018 & 12 orang \\
Jepang & & \\
\hline
\end{tabular}

\begin{tabular}{lll}
\hline Bahasa & Waktu Pelaksanaan & Jumlah \\
\hline Bahasa & Jumat/7 September & 15 orang \\
Inggris & 2018 & \\
Bahasa & Jumat/15 September & 10 orang \\
Jepang & 2018 & \\
Bahasa & Jumat/28 September & 16 orang \\
Inggris & 2018 & \\
\hline
\end{tabular}

\section{Langkah Pelaksanaan Program Inspirasi Bahasa Inggris}

Bahasa Inggris merupakan bahasa asing yang sudah dipelajari oleh para pelajar di Indonesia sejak bangku Sekolah Dasar atau Sekolah Menengah Pertama. Pembelajaran bahasa Inggris juga sudah sangat banyak kita dapati di lingkungan sekitar kita seperti melalui cerita, film, lagu, maupun siaran berita di radio maupun televisi. Walaupun demikian permasalahan tentang pembelajaran bahasa Inggris yang dinilai efektif dan berhasil masih terus diperdebatkan. Salah satu yang membuat kurang berhasilnya pembelajaran bahasa Inggris di sekolah adalah motivasi belajar para siswa. Jumlah durasi waktu yang disediakan di sekolah untuk mata pelajaran bahasa Inggris dianggap kurang baik oleh pihak pengajar maupun siswa, juga metode, teknik, dan bahan pengajaran bahasa Inggris yang dianggap kurang menarik bagi para siswa. Selain itu tidak semua siswa memiliki akses yang memadai terhadap bahasa Inggris. Keadaan seperti itu yang mempengaruhi motivasi belajar bahasa Inggris para siswa. Berdasarkan kondisi yang ada, maka kegiatan pelatihan bahasa Inggris bagi anak-anak di Panti Asuhan Harapan Remaja adalah sebagai berikut:

Tabel 2. Langkah Pelaksanaan Program Bahasa Inggris

\begin{tabular}{lll}
\hline Tahap & \multicolumn{1}{c}{ Tema } & \multicolumn{1}{c}{ Bahan Ajar } \\
\hline & & $\bullet$ Contoh kalimat \\
& & yang \\
& & menggunakan \\
& - Pengenalan & Simple Present \\
Tahap & kalimat & Tense \\
Ke - 1 & dengan & - Daftar \\
& Simple & pertanyaan \\
& Present Tense & dengan \\
& & menggunakan \\
& & Simple Present \\
& & Tense \\
\hline
\end{tabular}




\begin{tabular}{|c|c|c|}
\hline Tahap & Tema & Bahan Ajar \\
\hline $\begin{array}{l}\text { Tahap } \\
\mathrm{Ke}-2\end{array}$ & $\begin{array}{l}\quad \text { - Kalimat } \\
\text { dan cerita } \\
\text { dalam Bahasa } \\
\text { Inggris yang } \\
\text { menggunakan } \\
\text { Simple } \\
\text { Present Tense }\end{array}$ & $\begin{array}{l}\text { - Contoh dan } \\
\text { soal kalimat } \\
\text { dalam Bahasa } \\
\text { Inggris yang } \\
\text { menggunakan } \\
\text { Simple Present } \\
\text { Tense } \\
\text { • Gambar yang } \\
\text { berisikan kegiatan } \\
\text { sehari-hari }\end{array}$ \\
\hline
\end{tabular}

\section{Langkah Pelaksanaan Program Inspirasi Bahasa Jepang}

Kesadaran bahwa suatu bahasa berguna dan ada di sekitar kita, penting untuk menumbuhkan inspirasi dan motivasi belajar bahasa asing, terutama bahasa Jepang. Tidak seperti bahasa asing lainnya input bahasa Jepang sangat sedikit, apalagi bagi seseorang yang tidak belajar bahasa tersebut sangat sulit menyadari keberadaan bahasa tersebut disekitarnya. Untuk itu perlu untuk menemukan kondisi disekitar pembelajar yang memungkinkan pembelajar tersebut merasakan kemungkinan bersentuhan dan menggunakan bahasa tersebut. Oleh karena itu, pelaksana kegiatan abdimas mengadakan wawancara dengan pengurus panti asuhan dan pengamatan kondisi kegiatan berbahasa sebelum merancang pelatihan.

Berdasarkan hasil wawancara dengan pengurus panti asuhan dan pengamatan pelaksana, maka ada beberapa kondisi yang dapat digunakan untuk menumbuhkan inspirasi dan motivasi belajar bahasa asing khususnya bahasa Jepang, kondisi tersebut adalah sebagai berikut:

1. Adanya keluarga pengurus yang merupakan penutur asli bahasa Jepang dan sering berkunjung ke panti asuhan yang cukup dikenal peserta

2. Adanya pengunjung panti asuhan yang berasal dari Jepang.

3. Adanya kursus paduan suara yang pernah menyanyikan lagu berbahasa Jepang

4. Beberapa produk makanan dan minuman yang biasa dikonsumsi anak-anak/remaja ada yang menyelipkan bahasa Jepang pada label produk mereka dan dapat ditemui disekitar peserta, seperti buskuit "Pokky", minuman teh dengan merek "Nu," susu asam "Heavenly Blush", keripik kentang "Potabee" dll.
5. Beberapa iklan produk dan merek toko/restoran kejepangan yang menggunakan huruf Jepang, seperti "Hokahoka Bento", dapat dilihat disekitar panti asuhan.

Berdasarkan kondisi tersebut, maka rancangan pelatihan bahasa yang dilaksanakan adalah sebagai berikut.

Tabel 3. Langkah Pelaksanaan Program Bahasa Jepang

\begin{tabular}{|c|c|c|}
\hline Tahap & Tema & Bahan Ajar \\
\hline $\begin{array}{l}\text { Tahap } \\
\text { ke-1 }\end{array}$ & $\begin{array}{l}\text { - "Salam } \\
\text { dalam } \\
\text { bahasa } \\
\text { Jepang" } \\
\text { - "Huruf } \\
\text { Jepang di } \\
\text { sekitar kita" } \\
\text { - "Namaku } \\
\text { dalam } \\
\text { bahasa } \\
\text { Jepang" }\end{array}$ & $\begin{array}{l}\text { - Daftar salam } \\
\text { dalam bahasa } \\
\text { Jepang } \\
\text { - Daftar huruf } \\
\text { hiragana dan } \\
\text { katakana } \\
\text { - Foto-foto produk } \\
\text { yang } \\
\text { menggunakan } \\
\text { bahasa Jepang } \\
\text { - Produk yang } \\
\text { menggunakan } \\
\text { bahasa Jepang }\end{array}$ \\
\hline $\begin{array}{l}\text { Tahap } \\
\text { ke-2 }\end{array}$ & $\begin{array}{l}\text { - "Perkenalan } \\
\text { diri" } \\
\text { - "Lagu } \\
\text { Jepang" }\end{array}$ & $\begin{array}{l}\text { - Model } \\
\text { perkenalan diri } \\
\text { dalam bahasa } \\
\text { Jepang. } \\
\text { - Lirik lagu Jepang } \\
\text { yang sama juga } \\
\text { terdapat dalam } \\
\text { bahasa Indonesia. } \\
\text { "Chouchou"/"Bo } \\
\text { neka } \\
\text { Abdi"/"Melati } \\
\text { kenanga" }\end{array}$ \\
\hline
\end{tabular}

Pelatihan dilakukan secara interaktif dan koloboratif. Hal ini ditujkan untuk membangun sistem motivasi diri dari para peserta pembelajaran bahasa (Sung, 2013). Peserta tidak hanya mendengarkan penjelasan, akan tetapi terlibat secara aktif. Pada tahap pertama, peserta terlibat aktif menuliskan namanya dengan huruf katakana, menemukan huruf Jepang diprodukproduk Jepang, serta mencari cara bacanya dengan mengacu pada daftar huruf hiragana dan katakana. Pada tahap kedua peserta mempraktekkan perkenalan diri dalam bahasa Jepang di dalam grup dan presentasi perkenalan diri di depan seluruh peserta. Di bagian akhir 
tahap ke dua, peserta berlomba menyanyikan lagu "Chouchou(kupukupu)".

\section{HASIL DAN PEMBAHASAN}

Hasil kegiatan kelas penumbuhan inspirasi belajar bahasa asing dapat dilihat dari hasil angket yang disebarkan sebelum dan sesudah pelatihan. Angket yang dibagikan terdari dari pertanyaan mengenai data pribadi dan pertanyaan tentang ketertarikan belajar dan keinginan belajar dan menggunakan bahasa asing. Oleh karena jumlah kelas angket awal dan angket akhir disebarkan, maka angket yang diolah hanya angket yang dijawab oleh peserta yang hadir dari awal dan akhir pelatihan sebanyak 12 orang.

Berdasarkan hasil angket sebelum dan sesudah pelatihan, ditemukan bahwa terdapat peningkatan ketertarikan untuk belajar bahasa asing dari 'cukup tertarik' belajar bahasa asing menjadi 'tertarik' berbahasa Asing, sebesar $25 \%$, seperti yang digambarkan pada Gambar 1 . berikut ini.

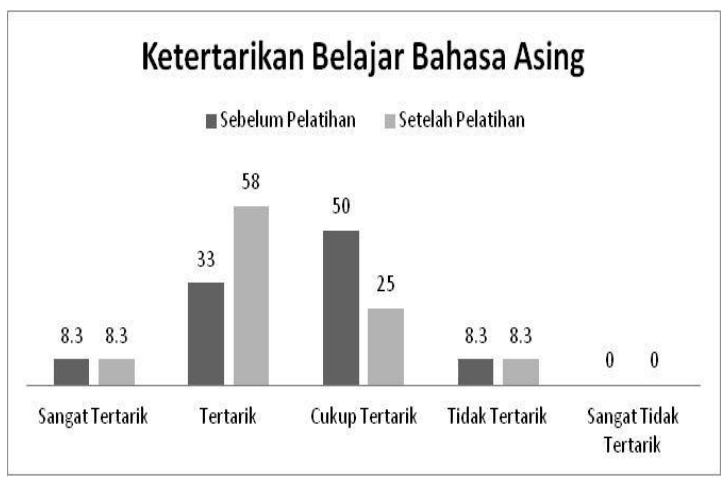

Gambar 1. Ketertarikan Belajar Bahasa Asing

Ketertarikan ini juga terlihat dari jawaban hasil pertanyaan angket mengenai keinginan menonton film bahasa asing tanpa alih bahasa. Seperti yang tergambar pada Gambar 2. berikut ini, terjadi peningkatan keinginan ('sangat ingin', 'ingin', 'cukup ingin') menonton film asing tanpa alih bahasa sebesar $33.7 \%$ dibandingkan dengan sebelum pelatihan.

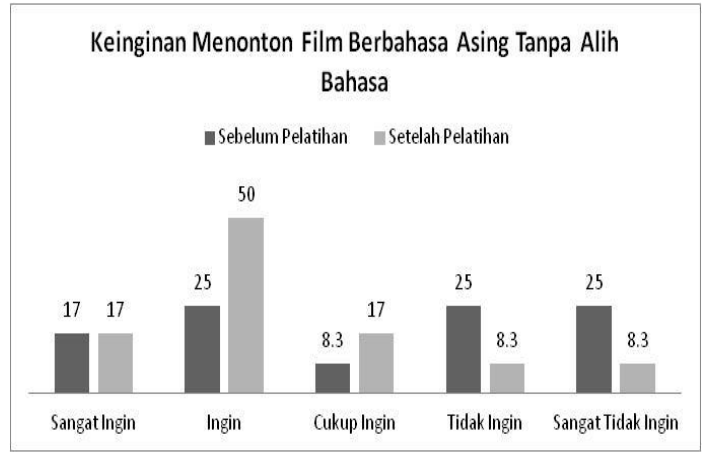

Gambar 2. Keinginan Menonton Film Berbahasa Asing Tanpa Alih Bahasa

Selain itu terlihat perubahan peningkatan ketertarikan siswa terhadap makna lagu berbahasa asing yang didengarnya. Hal ini dapat dilihat dari perubahan peningkatan jawaban 'sangat ingin' pada jawaban sesudah pelatihan sebesar $17 \%$ dari sebelum pelatihan seperti terlihat pada Gambar 3.

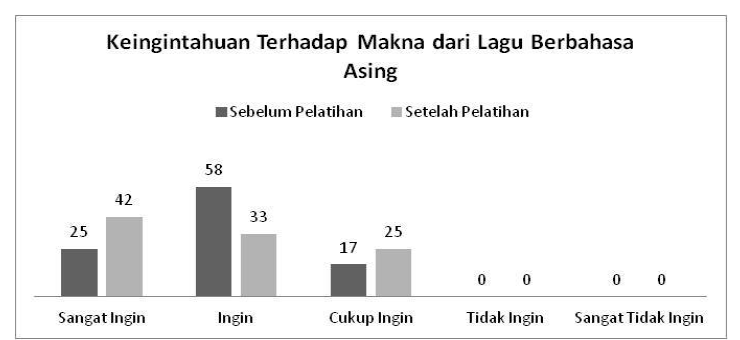

Gambar 3. Keingintahuan Terhadap Makna dari Lagi Berbahasa Asing

Demikian juga dengan ketertarikan peserta terhadap arti tulisan berbahasa asing di sekitar peserta. Terlihat peningkatan pada jawaban 'sangat ingin' sebesar 8\% sesudah pelatihan dibandingkan dengan sebelum pelatihan, akan tetapi masih sedikit (Gambar 4. ).

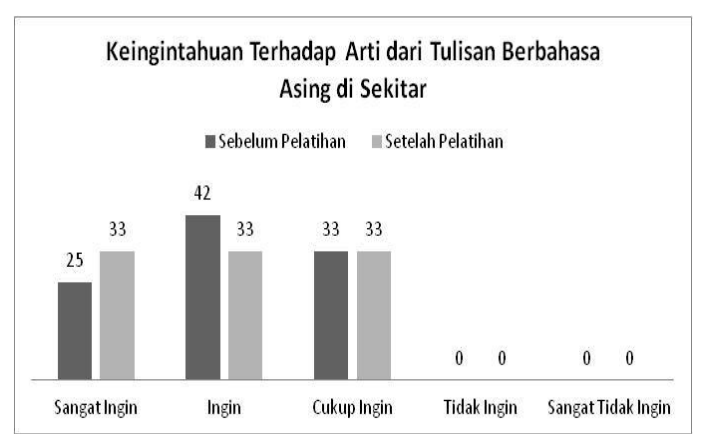

Gambar 4. Keingintahuan Terhadap Arti dari Tulisan Berbahasa Asing di Sekitar 
Untuk pertanyaan mengenai keinginan ('sangat ingin', 'ingin', 'cukup ingin') untuk mahir berbahasa asing terdapat peningkatan, akan tetapi tidak begitu tinggi, yaitu hanya sebesar $8 \%$ dibandingkan dengan sebelum pelatihan. Hal ini tergambar pada Gambar 5 berikut ini.

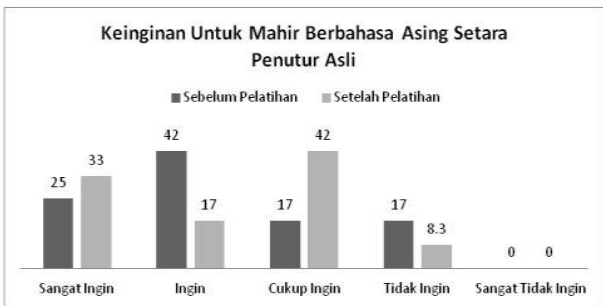

Gambar 5. Keinginan Untuk Mahir Berbahasa Asing Setara Penutur Asing

Akan tetapi seperti yang terlihat pada gambar 6 di bawah ini, tidak ada perubahan untuk pertanyaan mengenai keinginan untuk mencoba menggunakan bahasa asing terhadap orang asing dari sebelum dan sesudah pelatihan. Walaupun demikian terlihat seluruh peserta mempunyai keingingan ('sangat ingin', 'ingin', 'cukup ingin') untuk mencoba menggunakan bahasa asing terhadap penutur asli bahasa asing tersebut.

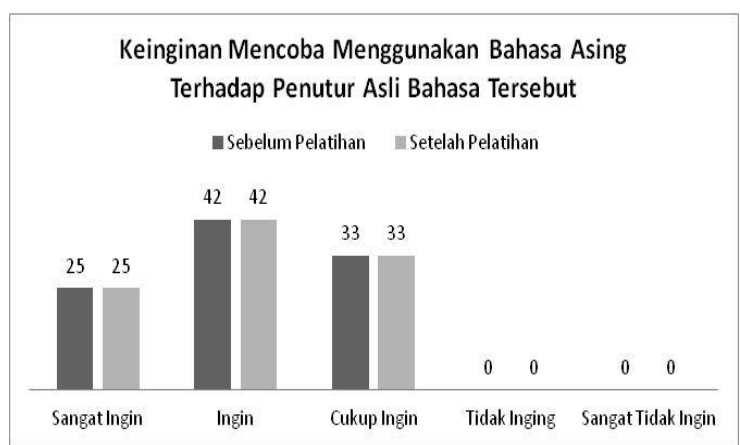

Gambar 6. Keinginan Mencoba Menggunakan Bahasa Asing Terhadap Penutur Asli Bahasa Tersebut

Sedangkan apabila dilihat dari motivasi belajar bahasa asing, maka dapat dilihat peningkatan motivasi untuk belajar asing selain sebagai pelajaran wajib di sekolah yaitu untuk memahami lagu dan film asing dan ingin bekerja di perusahaan asing (Gambar 7).

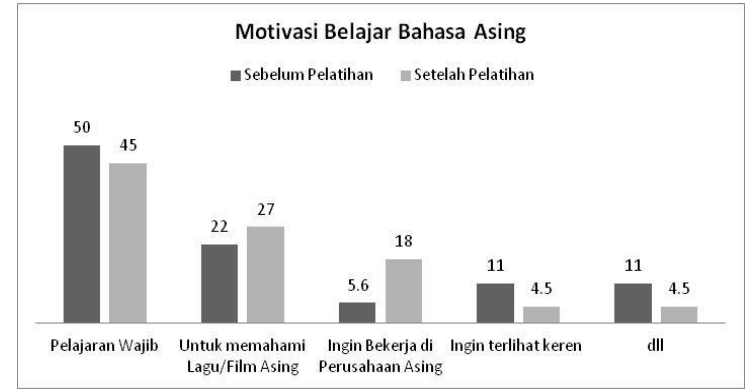

Gambar 7. Motivasi Belajar Bahasa Asing

\section{SIMPULAN DAN SARAN}

Berdasarkan hasil angket awal dan akhir kelas penumbuhan inspirasi belajar bahasa asing yang telah dipaparkan pada bab sebelumnya, maka dapat disimpulkan bahwa dengan adanya kelas penumbuhan inspirasi belajar bahasa asing telah meningkatan ketertarikan peserta untuk belajar bahasa asing. Ketertarikan ini tergambarkan pada peningkatan keinginan siswa untuk menonton film berbahasa asing tanpa alih bahasa, peningkatan keingintahuan peserta terhadap makna dari lagu berbahasa asing yang didengarnya dan arti dari kata-kata berbahasa asing disekitarnya. Dua tahap pelatihan yang menggunakan lagu dan juga bahasa asing yang ada disekitarnya sudah dapat menumbuhkan inspirasi sebagian peserta untuk belajar bahasa asing, walaupun masih rendah.

Keinginan peserta untuk mahir berbahasa asing juga mengalami peningkataan akan tetapi sangat sedikit dan tidak ada perubahan keinginan untuk mencoba menggunakan bahasa asing terhadap penutur asli. Hal ini dapat disebabkan karena jumlah pelatihan yang hanya dua tahap dan belum dirasakan manfaat sepenuhnya oleh peserta.

Akan tetapi dari segi motivasi terlihat peningkatan motivasi lain selain pelajaran wajib disekolah, yaitu untuk memahami lagu dan film asing, dan bekerja diperusahaan asing, ingin bisa berbicara bahasa asing (dll). Hal ini menunjukan bahwa beberapa peserta menyadari bahwa bahasa asing bermanfaat tidak hanya untuk nilai di sekolah akan tetapi pada kehidupan seharihari dan masa depan. 
Saran untuk kegiatan kelas penumbuhan inspirasi belajar bahasa asing, adalah; untuk menumbuhkan inspirasi diperlukan konsistensi dan jangka waktu yang panjang. Untuk itu kegiatan ini harus dilakukan dalam jangka waktu yang panjang dan berkala. Untuk bahan ajar dan pelatihan diperlukaan target yang dapat dijadikan motivasi peserta untuk belajar, seperti mengundang penutur asli datang ke panti asuhan atau datang ke even terkait negara asal bahasa untuk mencoba menggunakan bahasa, dll.

\section{DAFTAR PUSTAKA}

Alizadeh, M. (2016). The Impact of Motivation on English Language Learning. International Journal of Research in English Education Vol. 1 No.1.
Dornyei, Z. (2001). Motivational Strategies in The Language Classroom. Cambridge: Cambridge University

Kitjaroonchai, N. (2012). Motivation toward English Language Learning of Students in Secondary and High Schools in Education Service Area Office 4, Saraburi Province, Thailand. International Journal of Language and Linguistics Vol 1 No.1, hlm. 22-33.

Sepora, T., Mahadi, T., Jafari, S.M. (2012). Motivation, Its Types and Its Impacts in Language Learning. International Journal of Business and Social Science Vol. 3 No.24.

Sung, K. (2013). L2 Motivation in Foreign Language Learning. Journal of Language and Linguistic Studies Vol 9 No. 2 hlm. 19-30

Williams, M. \& Burden, R. (1997). Psychology for Language Teachers. Cambridge: Cambridge University Press. 